\title{
Clinical Profile of M ucormycosis: A Study from Teaching Hospital in North Karnataka, India
}

Rajoor UG *1, Mahabalshetti AD 2, Dhananjaya M ${ }^{3}$.

${ }^{* 1}$ Associate Professor, Department of Medicine, Koppal Institute of Medical Sciences, Koppal, State-Karnataka, India.

${ }^{2}$ Associate Professor, Department of Medicine, SDM College of Medical Sciences and Hospital, Sattur, Dharwad, State-Karnataka, India.

${ }^{3}$ Assistant Professor, Department of Medicine, SDM College of Medical Sciences and Hospital, Sattur, Dharwad, State-Karnataka, India.

\section{ABSTRACT}

Background and objectives: Mucormycosis is a relatively rare opportunistic fungal infection. It is one of the devastating infections of immunocompromised host. Though several studies were done in India and elsewhere on Mucormycosis, it has not been extensively studied of late. The objective of the study is to study the clinical profile of M ucormycosis in the northern part of Karnataka.

Materials and Methods: Our series compromised of 14 cases seen over a period of 5 years. Detailed history, clinical examination, laboratory investigations were carried out in all the cases.

Results: The study group consisted of 10 males and 4 females aged 20 - 70 years (mean 50 years). M ost of the patients in the study group had evident blackish nasal eschar and sinus disease. Cultures were positive for Mucorales in 08 cases. 11 patients were treated with amphotericin B in the doses ranging from $0.5-1.0 \mathrm{mg} / \mathrm{kg}$ up to a total of 2.6 grams, and duration of the treatment varied from 1 - 31 days.

Conclusions: Mucormycosis is a rare opportunistic fungal infection with rapidly progressive and fulminant course with often fatal outcome. A strong suspicion, prompt diagnosis with pathological confirmation and aggressive surgical treatment gives a better outcome.

KEY WORDS: Mucormycosis, Fungal, Amphotericin.

Address for correspondence: Dr. Amrut Mahabalshetti, Associate Professor, Department of Medicine, SDM College of M edical Sciences and Hospital, Sattur, Dharwad-580009, State-Karnataka, India. E-Mail: amrutdm@gmail.com

\begin{tabular}{|c|c|c|}
\hline \multicolumn{3}{|c|}{ Online Access and Article Informtaion } \\
\hline $\begin{array}{c}\text { Quick Response code } \\
\text { 四 }\end{array}$ & $\begin{array}{r}\text { International Jour } \\
\text { ww }\end{array}$ & $\begin{array}{l}\text { tegrative Medical Sciences } \\
\text { sciences.com }\end{array}$ \\
\hline $\begin{array}{c}\text { DOI: } 10.16965 \text { /ijims.2016.110 } \\
\text { Dis }\end{array}$ & $\begin{array}{l}\text { Received: 08-03-2016 } \\
\text { Reviewed: 08-03-2016 }\end{array}$ & $\begin{array}{l}\text { Accepted: 19-03-2016 } \\
\text { Published: 31-03-2016 }\end{array}$ \\
\hline
\end{tabular}

\section{INTRODUCTION}

Mucormycosis is an uncommon opportunistic infection, which represents the third most common angio-invasive fungal infection after candidiasis and aspergillosis and is considered as one of the most important medical complications in immunocompromised patients $[1,2]$.

Even though it is extremely rare, it has been reported from all corners of the world [1,3]. The majority of cases reported were either isolated communications or small, retrospective series [4]. M anagement of this devastating infection is still big challenge and is based on different strategies which include a rapid diagnosis, reduction of risk factors and rapid and aggressive antifungal agents with or without surgical debridement [5]. 
We report 14 cases of Mucormycosis retrospectively reviewing medical records of such patients and have made attempt to define clinical features, risk factors, diagnosis and treatment of such patients.

\section{MATERIALS AND METHODS}

Our series compromised of 14 cases seen over a period of 5 years. Data studied were patient age, gender, underlying disorders, clinical features, risk factors, diagnostic procedures and treatment including side effects and outcome. M icrobiological studies were performed on tissue biopsies. Samples were examined microscopically in a $20 \% \mathrm{KOH}$ mount and fungal culture was done in most cases. Histological studies included paraffin embedded $H \& E$, PAS and methenamine silver stained slides.

Statistical methods: Descriptive analyses were used to study the parameters. M icrosoft word and excel have been used to generate the graphs and tables.

\section{RESULTS}

The study group consisted of 10 males and 4 females aged $20-70$ years (mean 50 years). Almost all patients except one had at least one recognised underlying disorder (Table 1 ), of whom 13 had diabetes mellitus. Four patients had more than one risk factor.

Presenting symptoms and signs are listed in
Table 2. M ost of the patients in the study group had evident blackish nasal eschar and sinus disease was demonstrated in most of them (08), where neuroimaging was done (Table 3); this includes computed tomography scanning (07) and magnetic resonance imaging (01).

All patients underwent biopsies. Broad, non septate, branching hyphe were seen in all cases in $\mathrm{KOH}$ smears and in 14 histologic specimens showing tissue invasion. Cultures were positive for M ucorales in 08 cases, all of them showing rhizoids and collapsed columellae compatible with Rhizopus species. Mixed fungal infection was seen in one patient (Aspergillosis + candidal infection).

09 patients underwent surgical debridement procedures. 02 patients had an orbital exenteration. 08 patients were alive, 4 dead, 1 was referred to other centre and 1 was discharged against medical advice.

11 patients were treated with amphotericin $B$ in the doses ranging from $0.5-1.0 \mathrm{mg} / \mathrm{kg}$ up to a total of 2.6 grams, and duration of the treatment varied from 1 - 31 days. Incidence and severity of adverse effects of treatment are recorded in table 1. Reaction varied from mild to severe and was intolerable in 2 cases. These patients were treated with fiposomal form of the drugAmbisome. 07 cases had hypokalemia and 02 cases had renal dysfunction.

Table 1: Characteristics of mucormycosis patients.

\begin{tabular}{|c|c|c|c|c|c|c|c|c|c|}
\hline Patient & Age (yrs) & Gender & Underlying disorder & $\begin{array}{l}\text { Infecting } \\
\text { organism }\end{array}$ & $\begin{array}{c}\text { Medical treatment } \\
\text { Ampho B (mg/ day), } \\
\text { Cumulative dose (mg) }\end{array}$ & $\begin{array}{l}\text { Duration of } \\
\text { treatment } \\
\text { (days) }\end{array}$ & $\begin{array}{c}\text { Adv effects of } \\
\text { Ampho B }\end{array}$ & $\begin{array}{c}\text { Surgery (no of } \\
\text { procedures) }\end{array}$ & Outcome \\
\hline 1 & 64 & Male & DM, severe anemia & M & - & - & - & - & Alive \\
\hline 2 & 55 & Female & DM & M & $50(50)$ & 1 & NR & $\mathrm{Db}$ & Alive \\
\hline 3 & 38 & Male & DM, Pul.Koch & $\mathrm{R}$ & $50(600)$ & 12 & NR & $\mathrm{Db}$ & Dead \\
\hline 4 & 45 & Male & DM & $\mathrm{R}$ & $50(50)$ & 1 & None & - & Dead \\
\hline 5 & 60 & Male & DM, Steroids & $\mathrm{R}$ & 50 (1675), lipos & 31 & H+1 & $\mathrm{Db}+\mathrm{E}$ & Alive \\
\hline 6 & 52 & Female & DM, CKD & $R+A+C$ & $50(750)$ & 16 & H & $\mathrm{Db}$ & Dead \\
\hline 7 & 20 & Male & DM & $\mathrm{R}$ & $25(225)$ & 9 & + & $\mathrm{Db}$ & Alive \\
\hline 8 & 65 & Male & DM & $\mathrm{R}$ & $50(2600)$, lipo & 29 & H+1+ & $\mathrm{Db}+\mathrm{E}$ & Alive \\
\hline 9 & 70 & Male & DM & $\mathrm{R}$ & $25(300)$ & 12 & H & $\mathrm{Db}$ & Alive \\
\hline 10 & 25 & Male & AML & M & - & - & - & - & Referred \\
\hline 11 & 60 & Female & DM & M & $50(1150)$ & 15 & H & $\mathrm{Db}$ & Dead \\
\hline 12 & 35 & Female & - & $R$ & - & - & - & - & DAM A \\
\hline 13 & 50 & Male & DM & M & $25(500)$ & 20 & H & $\mathrm{Db}$ & Alive \\
\hline 14 & 63 & Male & DM & M & $50(800)$ & 17 & NR & - & Alive \\
\hline
\end{tabular}

DM - diabetes mellitus, CKD- chronic kidney disease, M-mucor racemosus, R-rhizopus, A-aspergillus, C-candida, NR-not recorded,+mild, ++ moderate,+H+severe, Db- debridement, E-orbital exenteration, DAMA- discharge against medical advice. 
Table 2: Clinical profile of patients.

\begin{tabular}{|c|c|c|c|c|c|c|c|c|c|c|c|c|}
\hline Patient & $\begin{array}{l}\text { Black nasal } \\
\text { eschar }\end{array}$ & Malaise & Chemosis & $\begin{array}{l}\text { Periorbital } \\
\text { cellulilitis }\end{array}$ & $\begin{array}{c}\text { Nasal } \\
\text { discharge }\end{array}$ & Proptosis & \begin{tabular}{|c|}
$\begin{array}{c}\text { ophthalmople } \\
\text { gia }\end{array}$ \\
\end{tabular} & $\begin{array}{l}\text { Decreased } \\
\text { vision }\end{array}$ & Fever & headache & $\begin{array}{l}\text { Altered } \\
\text { sensori }\end{array}$ & Palatal palsy \\
\hline 1 & - & + & - & - & - & - & - & . & + & + & . & . \\
\hline 2 & - & + & - & - & + & - & IC & + & + & + & - & - \\
\hline 3 & + & - & + & + & - & + & - & - & + & . & - & . \\
\hline 4 & . & . & . & + & + & . & IC & + & . & . & $\cdot$ & . \\
\hline 5 & + & + & + & - & - & + & c & + & . & - & . & - \\
\hline 6 & + & $\cdot$ & - & - & - & - & C & + & $\cdot$ & + & + & - \\
\hline 7 & + & . & . & - & + & . & - & + & . & . & - & . \\
\hline 8 & + & + & - & + & - & + & IC & + & + & + & - & - \\
\hline 9 & + & - & . & - & - & - & - & . & + & - & . & - \\
\hline 10 & $\cdot$ & + & $\cdot$ & - & - & - & $\cdot$ & $\cdot$ & + & $\cdot$ & . & - \\
\hline 11 & + & + & - & + & + & + & IC & - & + & . & + & - \\
\hline 12 & + & $\cdot$ & + & + & . & + & C & + & + & + & - & . \\
\hline 13 & $\cdot$ & + & $\cdot$ & . & $\cdot$ & . & - & - & . & + & . & . \\
\hline 14 & - & - & + & + & - & + & IC & - & - & - & - & - \\
\hline
\end{tabular}

+present, -absent, IC-incomplete, C-complete

\begin{tabular}{|c|c|c|c|}
\hline Patient & Neuroimaging findings & Involved sites & Predisposing local conditions \\
\hline 1 & - & $b^{\prime}$ & \\
\hline 2 & 5 & 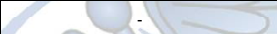 & A \\
\hline 3 & $\begin{array}{c}\text { CT ( PNS): Abnormal soft tissue mucosal } \\
\text { thickening/ fluid involving maxillary, ethmoid, } \\
\text { frontal and sphenoid sinuses. CT (brain): large ill } \\
\text { defined hypodense area involving left } \\
\text { basifrontal, frontal, corpus callosum with mild } \\
\text { mass effect over ventral horn of left lateral } \\
\text { ventricle. }\end{array}$ & $\begin{array}{l}\text { Left maxillary, ethmoid, frontal } \\
\text { and sphenoid sinus }\end{array}$ & inusitis \\
\hline 4 & (1) & - & \\
\hline 5 & $\begin{array}{l}\text { M RI: fluid collection in right sphenoid, ethmoid, } \\
\text { maxillary sinus. Small intracranial, extraaxial } \\
\text { extension in right medial temporal region with } \\
\text { partial thrombosis of right cavernous sinus. }\end{array}$ & $\begin{array}{l}\text { Right sphenoid, ethmoid, } \\
\text { maxillary sinus. }\end{array}$ & \\
\hline 6 & $\begin{array}{l}\text { CT (PNS): soft tissue swelling in the nasal cavity. } \\
\text { Inflammatory soft tissue tissue in bilateral } \\
\text { maxillary, ethmoid and focal sphenoid sinus. }\end{array}$ & $\begin{array}{l}\text { Bilateral maxillary, ethmoid and } \\
\text { focal sphenoid sinus. }\end{array}$ & \\
\hline 7 & $\begin{array}{l}\text { CT (PNS): Abnormal soft tissue mucosal } \\
\text { thickening/ fluid involving right maxillary, } \\
\text { ethmoid sinus with cellulitis. }\end{array}$ & Right maxillary, ethmoid sinus. & Chronic sinusitis \\
\hline 8 & $\begin{array}{c}\text { CT (PNS): Inflammatory soft tissue tissue in } \\
\text { bilateral maxillary, frontal, anterior ethmoid and } \\
\text { sphenoid sinus with erosion of medial wall of } \\
\text { left orbit. }\end{array}$ & $\begin{array}{l}\text { Bilateral maxillary, frontal, } \\
\text { anterior ethmoid and sphenoid } \\
\text { sinus. }\end{array}$ & Chronic sinusitis \\
\hline 9 & $\begin{array}{l}\text { CT (PNS): abnormal soft tissue with hypodense } \\
\text { contents involving right premaxillary, } \\
\text { retromaxillary and inframaxillary regions }\end{array}$ & Right maxillary sinus. & Chronic sinusitis \\
\hline 10 & - & - & - \\
\hline 11 & $\begin{array}{l}\text { СT (PNS): Abnormal soft tissue mucosal } \\
\text { thickening/ fluid involving right maxillary. }\end{array}$ & Right maxillary sinus. & Chronic sinusitis \\
\hline 12 & $\begin{array}{c}\text { CT (PNS): Inflammatory soft tissue tissue in } \\
\text { bilateral maxillary, frontal, anterior ethmoid and } \\
\text { sphenoid sinus with erosion of medial wall of } \\
\text { left orbit. }\end{array}$ & $\begin{array}{l}\text { Bilateral maxillary, frontal, } \\
\text { anterior ethmoid and sphenoid } \\
\text { sinus. }\end{array}$ & Chronic sinusitis \\
\hline 13 & - & - & - \\
\hline 14 & - & - & - \\
\hline
\end{tabular}

Table 3: Neuroimaging findings.

\section{DISCUSSION}

Mucormycosis is a devastating infection of immunocompromised hosts. The different forms of mucormycosis are rhino-orbital-cerebral, pulmonary, disseminated, cutaneous, gastro- intestinal and miscellaneous [6-8].

The mucoraceae are ubiquitous in nature [6-8]. This fungi gain entry to the body through the respiratory tract. They have affinity for arteries 
and grow along the internal elastic lamina, causing thrombosis and infarction. Progression of the disease from the nose and sinuses is either direct or leads to the vascular occlusion of the orbital contents. Intracranial involvement occurs also from the invasion by the way of the superior orbital fissure, ophthalmic vessels and cribriform plate, through the carotid artery, or possibly via a perineural route.

Due to the rarity of this infection, it is difficult to calculate accurately its incidence. In 2011 Mignogna et.al [5] reported in their study the annual incidence of mucormycosis in United States is approximately 500 cases per year.

The mean age of the patients was 50 years in our study. Talmi et.al [4] in their study reported mean age of the patients was 50 years. Commonly, Mucormycosis has shown an equal sex distribution. But in our there is slightly male predominance with ratio of male: female is 2.5:1.

Uncontrolled diabetes mellitus was the most common underlying predisposing disease in our series. While Talmi et.al [4] reported hematological malignancies as most common underlying disease.

Orbital and nasal findings are the most common presenting clinical features. Orbital involvement ranges from 58 to $100 \%$ of cases in our series. Similar findings were also observed by Talmi et.al [4] in their study (66-100\%). Orbital symptoms include loss of function of the $2^{\text {nd }}, 3^{\text {rd }}$, and $6^{\text {th }}$ cranial nerves with proptosis, ptosis, Chemosis, orbital pain, central retinal artery occlusion, conjunctival hyperaemia, dilated pupil and visual loss. Invasion of the eye globe is uncommon and was noted in only one of our cases.

Cultures were positive in 8 of 14 our cases, of which one case had mixed fungal infections. Talmi et.al reported similar findings in their study. Rhizopus was the most common infective agent in our study.

The treatment of Mucormycosis is mainly medical treatment with amphotericin B (amph $B)$ and surgical debridement. 11 received the treatment, 8 were treated with conventional amph $B$ and 3 were treated with liposomal amph $B$ and it is not widely used because of its cost.
Recognised side effects of amph B noted in our study are fever, chills, headache, nausea, vomiting, thromboplebitis, hypokalemia and azotemia.

Survival in mucormycosis patients dependent on multiple factors and early initiation of treatment is an important element. More than $60 \%$ of the patients survived in our study.

\section{CONCLUSION}

Mucormycosis is a rare opportunistic fungal infection with rapidly progressive and fulminant course with often fatal outcome. A strong suspicion, prompt diagnosis with pathological confirmation and aggressive surgical treatment gives a better outcome.

\section{REFERENCES}

[1]. Torres-Narbona M, Guinea J, Munoz P, Bouza E. Zygomycetes and zycomycosis in the new era of antifungal therapies. Rev Esp Quimioter 2007;20:375-86.

[2]. Chayakulkeeree M, Ghannoum MA, Perfect JR. Zycomycosis: the re-emerging fungal infection. Eur J Clin Microbiolog Infect Dis 2006;25:215-29.

[3]. Prabhu RM, Patel R. Mucormycosis and entomophthoramycosis: a review of the clinical manifestations, diagnosis and treatment. Clin Microbiolog Infect 2010; 10(suppl 1): 31-47.

[4]. Talmi YP, Reouven AG, Bakon M, Barshack I, Wolf M, Horowitz Z et.al. Rhino-orbital and rhino-orbitocerebral Mucormycosis. Otolaryngol Head Neck Surg 2002; 127: 22-31.

[5]. Mignogna MD, Fortuna G, Leuci S, Adamo D, Ruoppo $E$, Siano M, Mariani U. Mucormycosis in immunocompetent patients: a case-series of patients with maxillary sinus involvement and a critical review of the literature 2011;11:e533-540.

[6]. Baker RD. The phycomycoses. Anna N Y Acad Sci 1970; 174: 592-605.

[7]. Morduchowicz G, shmueli D, Shapira Z et al. Rhinocerebral Mucormycosis in renal transplant recipients: report of three cases and review of the literature. Rev Infect Dis 1986;8:441-6.

[8]. Yohai RA, Bullock JD, Aziz AA, et al. Survival factors in rhino-orbito-cerebral Mucormycosis. Surv ophthalmo 1994;39:3-22.

\section{How to cite this article:}

Rajoor UG, Mahabalshetti AD, Dhananjaya M. Clinical Profile of M ucormycosis: A Study from Teaching Hospital in North Karnataka, India. Int J Intg M ed Sci 2016;3(3):253-256. DOI: 10.16965/ ijims.2016.110 